\title{
Conjugalidade, parentalidade, regulação da cidadania e direitos humanos de lésbicas, gays e transgêneros no Brasil
}

Marital, parenting, regulation of citizenship and human rights of lesbians, gays and transgenders in Brazil

Agatha R. D.T. Guerra ${ }^{1}$ 


\section{Resumo}

A regulamentação dos direitos de casais homoafetivos, com ou sem filhos, as dimensões conjugais e parentais fora da heteronormatividade, a incansável luta pela visibilidade, a cidadania sexual e o respeito social foram alguns dos temas de artigos apresentados na Revista de Estudos Feministas por pesquisadores brasileiros no ano de 2006. Naquela época, o movimento de lésbicas, gays, bissexuais e transgêneros (LGBT) vivia a incerteza do reconhecimento da união homoafetiva como entidade familiar; a homofobia era um problema constante (como é até hoje) e a pauta de reivindicações incluía, entre outras coisas, o fim da discriminação pela orientação sexual. Com base nessas publicações, foi realizada uma breve análise acerca do assunto, uma reflexão daquele momento e as conquistas atuais do movimento LGBT no Brasil. Em 2013, o Conselho Nacional de Justiça (CNJ) garantiu a realização do casamento civil entre pessoas do mesmo sexo, e os empresários do setor de entretenimento e de turismo, atentos à demanda crescente desse público, começaram a investir abertamente em produtos e serviços destinados a essas pessoas, além de se mostrarem dispostos em capacitar funcionários para atendê-las adequadamente.

Palavras-chave: Homoparentalidade. Conjugalidade. LGBT. Cidadania. Turismo.

\section{Abstract}

The regulation of the rights of homosexual couples affective, with or without children, marital and parental dimensions outside of heteronormativity, the relentless struggle for visibility, sexual citizenship and social respect were among the topics of papers presented in the Journal of Feminist Studies by researchers Brazilians in 2006. At that time, the movement for lesbian, gay, bisexual and transgender (LGBT) lived the uncertainty of union recognition homoafetiva as a family; homophobia was a constant problem (as it is today) and the list of demands included, among other things, the end of discrimination by sexual orientation. Based on these publications, a brief analysis was conducted on the subject, reflecting that time and the current achievements of the LGBT movement in Brazil. In 2013, the National Council of Justice (CNJ) assured the realization of civil marriage between persons of the same sex, and entrepreneurs of the en- 
tertainment industry and tourism, aware of the growing demand of this public, openly began investing in products and services for these people as well as their willingness to empower employees to serve them properly.

Keywords: Homoparenthood. Conjugal. LGBT. Citizenship. Tourism.

\section{Introdução}

O presente texto faz parte de nossa reflexão acerca da temática conjugalidade, parentalidade, regulação da cidadania e direitos humanos de lésbicas, gays e transgêneros no Brasil e das considerações da disciplina Turismo, Trabalho e Gênero do Programa de Pós-Graduação do Centro de Excelência em Turismo da Universidade de Brasília (CET/UnB). A partir dos artigos reunidos no dossiê "Conjugalidades e Parentalidades de Gays, Lésbicas e Transgêneros no Brasil", publicado na Revista Estudos Feministas, no ano de 2006, referentes à visibilidade crescente de casais constituídos por pessoas do mesmo sexo com ou sem filhos e suas implicações. Considere-se ainda que esse assunto vai ao encontro do meu tema de dissertação do mestrado - O turismo LGBT em Brasília: Conquistas sociais e oferta de lazer para o segmento -, este texto apresenta algumas reflexões acerca dos dados obtidos na pesquisa do dossiê em questão. Além de uma breve análise das conquistas e retrocessos do movimento de lésbicas e gays, levando-se em consideração o período da publicação do referido dossiê, os avanços do movimento homossexual nos dias atuais, ressaltamos também neste artigo o grande interesse de empresários do setor de turismo, cultura e lazer em investir em produtos e serviços para o segmento, cientes da demanda com significativo poder de compra da maioria desse público.

\section{Conjugalidades, parentalidade de lésbicas, gays e transgêneros no Brasil.}

A discussão acerca dos sentidos da família brasileira atual, formada por casais fora dos padrões da heteronormatividade, vem ocorrendo com maior intensidade a partir da década de 1990. O modelo da tradicional família cede lugar aos vários tipos de arranjos familiares, os quais estão cada vez mais sendo aceitos socialmente, inclusive sendo legitimados pelo Governo Federal.

O termo parentalidade não consta em nossos dicionários e, segundo Mesquita (2013), é mais utilizado com o sentido próximo do francês parentalité e pelos ingleses parenthood, designando simultaneamente "paternidade" e "maternidade", ou seja, qualidade parental. Implica o envolvimento com os filhos e a relação com o outro elemento do casal. Enquanto conjugalidade, de acordo com Baldi (2011), está 
diretamente vinculado à experiência de "con-viver" ou viver com alguém, compartiIhando a experiência de uma vida em comum.

Os artigos aqui analisados datam de 2006, época em que o assunto da parentalidade e da conjugalidade de lésbicas, gays e transgêneros passou a constar com mais veemência dos debates políticos e acadêmicos de vários países capitalistas, principalmente os Estados Unidos e países europeus.

Quanto aos debates acadêmicos, segundo os organizadores do dossiê aqui analisado, foram desenvolvidos em dois campos de estudos: no campo de estudos feministas/de gênero e de estudos queer ${ }^{2}$ com autores como: Judith Butler Joan Scott e Miguel Vale de Almeida. No campo do pensamento social contemporâneo: Anthony Giddens, Elizabeth Roudinesco, Pierre Bourdieu, Zygmund Bauman, entre outros, discutem a relevância política das demandas LGBT.

No Brasil, os autores asseguram que os estudos acerca de pessoas LGBT têm como marco trabalhos de Carmem Dora Guimarães, Luiz Mott, Peter Fry, entre outros. A partir de 1990, as pesquisas passaram a destacar com maior ênfase a conjugalidade de pessoas do mesmo sexo, cujos primeiros trabalhos a respeito, considerados referências foram os de Jurandir Freire Costa e Maria Luíza Heilborn.

O Projeto de Lei 1.151/95, de autoria da então deputada Martha Suplicy, denominado de Parceria Civil Registrada (PCR), que estabelecia a união civil entre pessoas do mesmo sexo, obteve uma dimensão extraordinária para a época, aparecendo em todas as mídias, ganhando visibilidade, com diversas manifestações prós e contras de políticos, religiosos e ativistas LGBT, sendo ponto de calorosas discussões até entre populares. A partir daí, os brasileiros começaram a conviver com a ideia da existência de uma "família homossexual", cuja conjugalidade e parentalidade passaram a ter um contorno de legitimidade social.

Em 1995, o Brasil aparentava fazer parte do seleto grupo de países que discutia o amparo legal a relações homoafetivas com a apresentação do projeto de Lei da Parceria Civil Registrada (PCR). Entretanto, até 2006, o projeto encontrava-se arquivado sem nunca ter entrado em pauta na Câmara dos Deputados e não se vislumbrava que os direitos conjugais e parentais de casais de lésbicas e de gays viessem a ser assegurados em curto prazo. Segundo Uziel, Mello e Grossi (2006, p. 482):

Enquanto aqui, no Brasil, a oposição religiosa e as posições machistas, sexistas e homofóbicas dos parlamentares têm sido os principais

2 Queer é uma expressão em inglês cujo significado é uma ofensa, uma forma pejorativa de designar homossexuais, como: estranhos, ridículos, raros. Este termo é assumido por uma parte do movimento homossexual como forma de contestação. É muito utilizado no contexto político de gênero. 
responsáveis pelos entraves à aprovação da PCR, quase vinte países já aprovaram leis que asseguram amparo a uniões civis entre homossexuais.. A Holanda (1/4/2001), a Espanha (29/6/2005), a Bélgica (30/1/2003) e o Canadá (28/6/2005) reconhecem a possibilidade de casamento civil entre pessoas do mesmo sexo, com plenos direitos parentais no caso dos dois primeiros países mencionados.

Para os autores, o Brasil, país que despontava nas lutas sociais contemporâneas, com a possível aprovação da lei da PCR (que se encontrava parada na Câmara dos Deputados desde 1995), passava a ficar mais próximo aos países fundamentalistas no tocante à garantia de direitos da família para homossexuais e transgêneros, ou seja, havia retrocedido em muito.

Os direitos dos homossexuais até 2006 avançavam lentamente no âmbito do Poder Legislativo. Entretanto, algumas conquistas eram obtidas quanto ao reconhecimento da legitimidade da união conjugal e do exercício parental junto ao Poder Judiciário, ou seja, o movimento LGBT garantia alguns direitos individuais por meio de demandas judiciais, os quais passavam a valer para todos do movimento.

Não existiam no Brasil conceitos e termos que fossem aceitos socialmente referentes à filiação e à parentalidade homoerótica. No entanto, utilizava-se o termo homoparentalidade, criado na França em 1990, pela Associação de Pais e Mães Gays e Lésbicas. Controvérsias de pesquisadores à parte, esse termo foi considerado politicamente favorável, tendo em vista que proporcionava a visibilidade LGBT para essa demanda.

\section{Acesso ao casamento no Brasil: Uma questão de cidadania sexual}

Em 2006, e ainda hoje no Brasil, existe uma forte corrente (principalmente religiosa) que considera o modelo heterossexual como o único, correto, saudável e aceitável no que diz respeito à conjugalidade, parentalidade e, por conseguinte, exclusivamente aquele que teria acesso à instituição do casamento.

Segundo Lorea (2006), a possibilidade de casamento entre homossexuais não depende de uma nova legislação reguladora, pois a Constituição Federal de 1988 veda qualquer modalidade de discriminação, devendo ser asseguradas a gays e lésbicas as mesmas prerrogativas legais garantidas aos demais cidadãos. $O$ fato é que $o$ acesso ao casamento não poderia estar condicionado a pessoas que pertençam a determinada orientação sexual.

Em seu artigo, Lorea (2006, p.489) enfatiza a questão de que nosso país é laico e pluralista "mantendo-se o Estado brasileiro equidistante de todas as confissões re- 
ligiosas, sendo-Ihe vedado estabelecer aliança com qualquer igreja". Nesse sentido, ele lembra que, por ser um Estado laico, os únicos símbolos da Pátria são a bandeira, o hino, as armas e o selo, mas existe uma proliferação de símbolos religiosos em prédios públicos, em especial no Senado, na Câmara e no Supremo Tribunal Federal. Na verdade, a negação da laicidade do Estado brasileiro é uma grave violação do texto constitucional.

A relevância de vivermos em um Estado laico adquire maior visibilidade quando se enfrentam temas que estão afetos aos direitos sexuais, sendo fundamental que se possa debater questões vinculadas à sexualidade à luz do ordenamento jurídico vigente e não sob uma perspectiva religiosa (LOREA, 2006 p. 490).

É do conhecimento geral a posição contrária das igrejas católicas e evangélicas em relação às uniões de lésbicas e gays. Nesse sentido, o autor faz um grave alerta para a atuação e influência religiosa dentro dos poderes da República e conclama para que as decisões, principalmente do Poder Judiciário, não sejam pautadas a partir de motivações de cunho religioso, em especial no que diz respeito aos direitos sexuais e da cidadania sexual. Em um Estado laico como o nosso é de fundamental importância que o único livro ao qual legisladores, governantes e juízes devem obediência é a Constituição.

A diversidade sexual estaria amparada pelo artigo 3이 da Constituição Federal ${ }^{3}$. Nesse contexto, a resistência ao acesso ao casamento de homossexuais está intrinsecamente ligada à discriminação pela orientação sexual e por isso lésbicas e gays não poderiam exercer plenamente sua cidadania.

Lorea (2006) aponta que, dentre as possíveis reservas (resistências) vindas do senso comum para justificar tratamento distinto aos casais homossexuais, as mais recorrentes são: é a homossexualidade uma patologia? O casamento entre pessoas do mesmo sexo representa um risco para a sociedade? A adoção de crianças por casais homossexuais põe em risco a integridade física ou mental dessas crianças? Ele não levanta questões religiosas por considerar que elas não dizem respeito a um Estado laico.

Deve-se atentar para o fato de que o Conselho Federal de Medicina (CFM) e a Organização Mundial da Saúde (OMS) não consideram a homossexualidade uma patologia há mais de 20 anos. O Conselho Federal de Psicologia (CFP), em sua Resolução 01/1999, afasta a possibilidade de tratamento com vistas à "cura" da homossexualidade. Entretanto, um grande retrocesso para as causas LGBT brasileira ocorreu

3 "Promover o bem de todos, sem preconceitos de origem, raça, sexo, cor, idade e quaisquer outras formas de discriminação [...] Todos são iguais perante a lei, sem distinção de qualquer natureza." (BRASIL, 1988 apud LOREA, 2006 p. 491). 
em 2013: essa comunidade esteve envolvida em meio à polêmica da aprovação do Projeto de Lei da Comissão de Direitos Humanos e Minorias da Câmara dos Deputados $^{4}$, que determinava o fim da proibição, pelo Conselho Federal de Psicologia, de tratamentos que reverteriam à homossexualidade, a qual ficou conhecida como "Lei da cura gay". Após vasta discussão no âmbito político e na sociedade, ela foi devidamente retirada de tramitação na Câmara Federal e arquivada.

A Associação Americana de Antropologia (apud ARRIADA, 2006 p. 492) divulgou nota pública em que ressalta:

[...] pesquisas antropológicas [...] não fornecem qualquer tipo de evidência científica que possa embasar a ideia de que a civilização ou qualquer ordem social viável dependa do casamento ser uma instituição exclusivamente heterossexual. [...] fundamentam a conclusão de que um imenso leque de tipos de famílias, incluindo famílias baseadas em parcerias entre pessoas do mesmo sexo, podem contribuir na promoção de sociedades estáveis humanitárias.

Dentro dessa perspectiva, enquanto a ciência apresenta resultados de suas pesquisas, existe uma parcela da sociedade cuja visão dogmática tende para o preconceito e discriminação para com os homossexuais. $O$ cerne da questão parte do preconceito social que ainda hoje caminha para a aceitação da união homoafetiva como de fato uma união familiar. Quanto à demanda de criação ou adoção de filhos por casais homossexuais, Lorea (2006) salienta que em resultados de pesquisas nacionais e internacionais não constam restrições capazes de afastar essa possibilidade.

As resistências à aceitação de famílias formadas por casais de homossexuais baseiam-se no fato de que o movimento de gays e lésbicas, ao pedir direitos iguais, afronta e abala as bases em que foram constituídas as sociedades, como a repressão sexual e a heteronormatividade.

Em março de 2004, o Estado do Rio Grande do Sul, em uma medida inédita, tornou-se o primeiro Estado brasileiro a determinar que os cartórios de títulos e documentos registrassem contratos de união civil entre pessoas do mesmo sexo. Essa ação, à época, foi considerada como uma grande conquista pelo movimento LGBT, o qual já não contava mais com a aprovação do Projeto de Lei da ex-deputada Marta Suplicy, que regulamentava a questão e que continuava sem aprovação pela Câmara dos Deputados. A partir dessa data e até 2006 - ano base dos artigos aqui analisados -, outros cartórios brasileiros, em maior ou menor grau, registraram esse tipo de contrato.

Apesar desse avanço do movimento LGBT, ainda persistia o modelo de casamen-

4 Presidida pelo deputado Marco Feliciano, pastor evangélico, abertamente favorável a essa lei -, 
to distinto para heterossexuais e homossexuais, o que continuava sendo um claro tratamento discriminatório. Entretanto, essa parceria civil seria interpretada como a alternativa gay ao casamento heterossexual. Somente em maio de 2013 (exatos nove anos após a liberação do contrato de união civil) o Conselho Nacional de Justiça (CNJ) aprovaria uma resolução legalizando, na prática, o casamento entre pessoas do mesmo sexo em todo o território brasileiro.

A primeira magistrada e primeira desembargadora do Rio Grande do Sul, Maria Berenice Dias, reconhecida por sua incansável luta pelas causas sociais, sofreu discriminações e contratempos ao longo de sua carreira de juíza ${ }^{5}$ por ser mulher em um ambiente majoritariamente masculino e não menos machista. Com os infortúnios enfrentados na carreira de jurisdição, principalmente pela questão de gênero, ela passou a se dedicar aos segmentos da sociedade cujos direitos não são reconhecidos: as minorias discriminadas. Foi pioneira na defesa das questões LGBT por entender que não havia nenhuma norma que identificasse esses casais como uma família:

Não assegurar qualquer garantia nem outorgar quaisquer direitos às uniões homoafetivas infringe o princípio constitucional da igualdade, revela discriminação sexual e violação aos direitos humanos, pois afronta o direito ao livre exercício da sexualidade, liberdade fundamental do ser humano que não admite restrições de quaisquer ordens (DIAS, 2000 apud MOTT, 2006 p. 509).

A desembargadora continua atuando na causa pelas minorias e se especializou em direito homoafetivo, lançou algumas obras acerca do assunto, cuja intenção é dar visibilidade e impor respeito às diferenças sexuais, abordando aspectos relacionados ao tema. Por entender que as relações homoafetivas devam ser consideradas como entidades familiares, não caberia a discriminação aos casais do mesmo sexo, cujos direitos deveriam ser assegurados legalmente, conforme salientou:

Se vivemos em um país livre - e vivemos -, todos são merecedores da tutela jurídica, sem qualquer distinção de cor, religião. Sexo ou orientação sexual. Em um Estado que se quer democrático de direito, o princípio da liberdade nada mais significa do que o direito de não sofrer discriminação por ser diferente (DIAS, 2008 p.174).

\section{A cidadania de gays, lésbicas e transgêneros no Brasil: homoafetividade e direitos humanos}

Desde 1985 e 1993, respectivamente, que o Conselho Federal de Medicina e a Organização Mundial de Saúde excluíram o código 302.0 da Classificação Internacional de Doenças, o qual designava a homossexualidade como um "desvio e transtorno sexual". Até

5 Aposentou-se em meados de 2008. 
então, a palavra utilizada era "homossexualismo", cujo sufixo "ismo" está diretamente relacionado a patologias. A palavra homossexualidade passou a ser utilizada como um estilo de comportamento, considerada como uma orientação sexual, um processo interno cuja designação está ligada ao interesse e atração sexual por pessoas do mesmo sexo e não uma doença ou "opção", afinal ninguém opta por ser homossexual.

Dentre as "minorias sociais" no Brasil, e na maior parte do mundo, os homossexuais são considerados as principais vítimas do preconceito e da discriminação. Em 1990, conforme aponta Mott (2006), foi aprovada a Lei Orgânica Municipal proibindo a discriminação por orientação sexual a qual foi adotada por 74 municípios de norte a sul do País e por três constituições estaduais - Mato Grosso, Sergipe e Distrito Federal. Em maio de 2004, foi lançado o Programa Brasil Sem Homofobia - Programa Brasileiro de Combate à Violência e à Discriminação contra Gays, Lésbicas, Transgêneros e Bissexuais, e de Promoção da Cidadania Homossexual. Essas ações afirmativas foram alcançadas por meio da incansável luta do movimento LGBT.

Apesar dessas leis e considerando a Declaração dos Direitos Humanos, o movimento LGBT convive diariamente com práticas que os excluem dos direitos básicos e com atos de violência declaradamente homofóbica. Mott (2006, p. 513) atenta para relatórios apresentados até àquela época a respeito da violência sofrida por homossexuais no Brasil:

O quadro descrito nos últimos relatórios é aterrador e revoltante, comprovando que a intolerância, violência e assassinatos de gays, lésbicas e travestis tem se mantido nos últimos anos praticamente nos mesmos patamares de selvageria e impunidade.

Em 2005, o Brasil realizou a maior parada gay do mundo com mais de dois milhões e meio de manifestantes lésbicas, gays e simpatizantes, em São Paulo. Esse evento, bastante representativo para o movimento LGBT, foi considerado como um marco da visibilidade da minoria sexual. Diante de número tão expressivo, os organizadores da parada passaram a vislumbrar possibilidades de uma maior aceitação da causa homoafetiva em nosso país.

Mott (2006, p. 515) diz que "os homossexuais são a última tribo romântica do mundo: enquanto diminui o número de heterossexuais se casando, lésbicas e gays lutam no mundo inteiro, inclusive no Brasil, para ter o direito de se casar". O reconhecimento legal do casamento entre homossexuais significa uma garantia recíproca para o casal, idêntica aos dos heterossexuais.

A Dinamarca foi o primeiro país a legalizar a união entre pessoas do mesmo sexo. $\mathrm{Na}$ África, segundo Mott (2006), inúmeras tribos permitem casamento entre muIheres. Entre os índios Tupinambás, desde a época da descoberta do Brasil, havia 
homens que viviam como casais. O "Batalhão dos Amantes" de Esparta era todo constituído de "casais" homossexuais. Goethe (apud MOTT, 2006 p. 517) dizia que a "homossexualidade é tão antiga quanto a própria humanidade." Assim como historicamente se tem conhecimento da existência de casamentos homossexuais em outras épocas. Dentro dessa perspectiva, Mott (2006, p. 516) enfatiza que "não há razão histórica, lógica ou ética, a não ser o preconceito homofóbico, que justifique a exclusão dos gays e lésbicas do direito universal de terem sua homo-conjugalidade reconhecida." A legalização da união homossexual irá contribuir para a desconstrução da imagem, muitas vezes equivocada, de que lésbicas e gays são promíscuos, incapazes de um amor verdadeiro, durável e de uma vivência conjugal e parental.

Atualmente as conquistas LGBT têm avançado muito no Brasil: em 2013, o ConseIho Nacional de Justiça garantiu a realização do casamento civil de lésbicas e gays, além de proibir os cartórios de se recusarem a fazer a conversão de união estável (aprovada pelo STF em 2011) de homossexuais em casamento. Havia muita resistência por parte de alguns cartórios em efetivarem essa conversão.

\section{Conjugalidade envolvendo travestis que se prostituem}

Dentro do movimento LGBT é muito discutida a questão da conjugalidade e parentalidade de lésbicas e gays, inclusive pela maior visibilidade alcançada por essas pessoas. No entanto, o universo conjugal das travestis não é muito enfocado devido ao estigma que é associado a esse grupo, principalmente por estar ligado diretamente à prostituição. Partindo dessa premissa, Pelúcio (2006), utilizando-se de uma abordagem antropológica, analisa três experiências de conjugalidade envolvendo travestis que se prostituem. São analisados três tipos de arranjos conjugais: mulher/homem, homem/homem e mulher/mulher.

O conceito de travesti, segundo a autora, está estreitamente vinculado ao de classe: a maior parte procede das classes baixa ou média baixa. Deve-se esclarecer que o termo usual de tratamento é "a travesti", no sentido feminino da palavra. Travestis são pessoas cujo gênero é masculino, e na maioria das vezes se percebem como homens, mas se vestem como mulheres, alteram algumas partes do corpo para aproximá-lo do gênero feminino (entre outros procedimentos cirúrgicos/estéticos tomam hormônios e aplicam silicone nos seios), sem, no entanto se submeter a cirurgia de retirada da genitália - o que as difere das pessoas transgêneros -, com a qual convivem sem problemas. Sentem-se atraídas sexualmente por homens.

A autora considerou pouco convencional as relações de conjugalidade envolvendo as travestis assim como a questão de, na maioria das vezes, um dos cônjuges se prostituir 
para garantir a subsistência do casal, e, no caso, tendo a anuência de seu par. Essa situação, principalmente entre travestis e homens ocorre na clandestinidade por receio - delas - de deteriorar a relação. A partir dessa questão, Pelúcio (2006, p. 524) salienta que:

Tudo isso torna a vida social de ambos menos previsível. Não há um script a seguir, uma vez que o modelo de conjugalidade que têm à disposição é o de heterossexuais, para os quais estão previstos papéis definidos como os de pai e mãe; esposo e esposa; provedor e administradora, entre outras.

Os papéis do casal entre travesti/homem, travesti/travesti são sempre bem definidos, ou seja, é latente quem é o "homem" e a "mulher" dentro da relação. O gênero ultrapassa a questão do sexo, pois se faz necessário, dentro dessa concepção, se aproximar do que seria mais usual, correto, numa perspectiva heterossexual. A vertente masculina e feminina obrigatoriamente, entre eles, deve estar presente e bem definida.

A conjugalidade nas relações das travestis, muitas vezes se resume ao gueto, pois dificilmente elas serão aceitas fora dele como um "casal". O histórico de vida dessas pessoas foge dos padrões comportamentais exigidos socialmente. Em geral, elas saem de casa na adolescência e, sem estudos ou qualificação profissional, para se sustentar, passam a se prostituir nas ruas. Quando são encarceradas por algum motivo, tornam-se vítimas de vários tipos de abusos em presídios, assim como gays e transgêneros. Atualmente, os Estados de Mato Grosso, Rio grande do Sul, Paraíba e Minas Gerais já reservam espaços exclusivos para detentos homossexuais, transexuais e travestis. Embora ainda não exista uma regulamentação específica para esses casos, o movimento LGBT considera iniciativas desse porte como uma grande conquista.

Atentas aos espaços que Ihes cabe em uma relação afetiva e, principalmente, das dificuldades advindas ao se unir a outra pessoa, assim mesmo, elas sonham em ter uma vida a dois, espelhada na conjugalidade heteronormativa com casa, marido, um trabalho digno com remuneração adequada e até filhos. As travestis anseiam por serem aceitas socialmente e desejam manter relacionamentos conjugais e parentais da forma tradicional monogâmica e não comerciais de sexo.

\section{Uma família de mulheres: homoparentalidade na periferia de São Paulo}

As mulheres historicamente sempre foram tratadas como cidadãs de segunda classe, simplesmente como sexo frágil, cujo papel social era reduzido tão somente aos cuidados do lar e à procriação. A discriminação e o preconceito imperavam soberanos contra as mulheres durante séculos. Atualmente, o papel da mulher na sociedade não é mais a de simples coadjuvante. A mulher do século XXI possui maior autonomia sobre sua vida e seu corpo, conhece seus direitos, ocupa o alto escalão 
de cargos públicos e políticos, comanda nações, universidades e empresas.

Apesar das várias conquistas, elas ainda são submetidas a violências sexuais, agressões físicas, morais e psicológicas. Ainda em 2006, foi sancionada pelo então presidente do Brasil, Luiz Inácio Lula da Silva, a Lei 11.340, conhecida como Maria da Penha, a qual proporcionou maior rigor nas punições da violência doméstica e familiar contra as mulheres. Por isso, faz-se necessário que as questões de gênero no Brasil e no mundo sejam discutidas no âmbito da sociedade e do Estado, em virtude da importância de seus direitos e da permanente busca de igualdade.

A conjugalidade e a parentalidade das lésbicas vai ao encontro dessa busca das mulheres pelo reconhecimento, pelos direitos e, no caso, principalmente pelo respeito à sua orientação sexual. Se as mulheres heterossexuais enfrentam adversidades para alcançar seus objetivos dentro da sociedade, o mesmo em dobro ocorre com as homossexuais, as quais têm que enfrentar inclusive a discriminação do próprio gênero que está em constante luta contra o preconceito.

Nesse sentido, Medeiros (2006) fez um trabalho etnográfico com uma família homoparental moradora da periferia de São Paulo, formada por Flávia, uma mulher negra, filha de santo, mãe de duas filhas (de um casamento heterossexual), militante política (à época desempregada), e Luiza, deficiente visual, presidente do Conselho da Prefeitura, pelo qual ela não é remunerada. A renda delas advém da aposentadoria por invalidez de Luiza. Elas, lésbicas assumidas, correspondem ao que bem denominou Luiza, a "exclusão dentro da exclusão":

Quando eu vou me apresentar em algum seminário, algum lugar, e eu falo que sou lésbica, negra, da periferia, mãe, do candomblé, e que minha companheira tem deficiência, as pessoas ficam loucas, cada uma querendo pegar uma dessas especificidades (MEDEIROS, 2006, p. 537).

Elas têm a exata noção das dificuldades em ser um casal de lésbicas em um bairro da periferia preconceituoso, homofóbico e com histórico de agressão e violência contra homossexuais. Outros casais que participaram da pesquisa afirmaram que não se sentiam seguros em assumir sua condição para a comunidade. Por isso a questão de se assumir perante essa comunidade parte do pressuposto que a lesbianidade não é uma questão de escolha, de experiência e sim algo de nascença. Medeiros (2006) aponta que "diante dessa irredutivel constatação, o que caberia ao âmbito da opção é, ou militar em torno da "visibilidade" ou escamotear aos olhos públicos essa condição".

Luiza e Flávia estão vinculadas a um movimento social, por isso conseguiram o respeito de sua comunidade, e sua homoparentalidade implicam criar as filhas sem esconder nada delas e dando espaço para que elas se manifestem em assuntos 
referentes à questão da lesbianidade. A criação das filhas é recoberta de cuidados para que não sofram lesbofobia na escola e na comunidade. Essa família de muIheres tem os mesmos desejos, anseios e angústias de um modelo tradicional de conjugalidade e parentalidade heterossexual, mas com a agravante de ter que lutar constantemente contra a discriminação e provar sua capacidade de ser uma família.

\section{A visibilidade atual do movimento LGBT e seu potencial de consumo turístico}

O momento atual vivenciado pelo movimento de lésbicas, gays, bissexuais e transgêneros, no mundo todo, é de avanços e conquistas. O reconhecimento de casais homossexuais como uma família levou empresários e governos a ter outra percepção deste segmento e sinalizar favoravelmente no sentido de apostar nesse público e investir em entretenimento, lazer e turismo inclusivo.

No Brasil, alguns empreendedores atentos à movimentação do mercado, constataram que o público LGBT representa um filão que está ávido por diversão e que, em sua maioria, possui um poder aquisitivo de compra superior ao de famílias/casais tradicionais. A nova formação familiar - uma parte considerável com filhos - é um potencial consumidor. Nessa perspectiva, após a conquista do casamento civil, a sociedade passou a lidar com mais respeito à relação homoafetiva. Casais do mesmo sexo passaram a se sentir mais seguros para exercer plenamente seus direitos e frequentar qualquer tipo de ambiente com seus parceiros sem a necessidade de confinar-se em guetos.

Empresários e governo, cientes dessa fatia de mercado que não para de crescer, estão cada vez mais se adaptando às necessidades do segmento LGBT, procurando atendê-lo melhor, evitando que sofram preconceitos e intolerância. Para tanto, investem na capacitação de seu pessoal para lidar adequadamente com a diversidade. A visibilidade desse público oportunizou investimentos no setor de consumo de bens, viagens, lazer e hotelaria, com vistas a satisfazer essa clientela e obter maiores lucros.

O mercado turístico vem se aprimorando para acolher a grande procura por destinações ou eventos onde esse segmento possa socializar-se, divertir-se sem ressalvas. Agências de turismo têm alcançado sucesso com esse segmento, investindo em viagens que contemplem as necessidades da nova família brasileira, procurando um turismo inclusivo, considerando-se a crescente aceitação da sociedade brasileira, dessa modalidade/categoria relacional.

\section{Considerações finais}


Os artigos aqui analisados, escritos em 2005/2006, refletiam o desejo dos casais homossexuais em ter direitos conjugais e parentais idênticos aos heterossexuais, por considerarem que a instituição família não deveria se restringir ao âmbito da orientação sexual. Em todos eles aparecia nitidamente essa preocupação e a busca por alcançar tal objetivo.

Em 2006, há exatos sete anos, o mundo se encontrava dividido na tentativa da globalização; a população se assustava com novos testes nucleares; no Chile foi eleita a primeira mulher para comandar o país; Lula - um ex-metalúrgico - era reeleito presidente do Brasil; o primeiro astronauta brasileiro foi ao espaço; a Lei Maria da Penha foi sancionada aumentando o rigor quanto às agressões contra as mulheres; a Parada do Orgulho LGBT de São Paulo reuniu mais de dois milhões de participantes com o tema "Homofobia é crime: direitos sexuais são direitos humanos". $O$ debate acerca dos direitos dos homossexuais começava a ganhar maior espaço, visibilidade e aceitação na sociedade. $O$ mundo estava definitivamente adentrando de fato no século XXI, e os prognósticos para os casais homoafetivos eram alvissareiros.

O movimento LGBT tem crescido mundialmente e vem obtendo visibilidade nas últimas décadas, apesar de ser tema de discussão dos direitos humanos e das políticas públicas há muito tempo. Entretanto, no Brasil, somente em 2013 o movimento LGBT obteve uma grande conquista: o Conselho Nacional de Justiça garantiu a realização do casamento civil de lésbicas e gays, além de proibir os cartórios de se recusarem a fazer a conversão de união estável de homossexuais (aprovada pelo STF em 2011). É o reconhecimento tão desejado da conjugalidade entre casais do mesmo sexo.

Cientes da demanda crescente do segmento homossexual e atentos aos bons resultados mundiais obtidos com esse segmento do mercado, em virtude de suas conquistas e visibilidade, empresários brasileiros do setor de turismo, bares, restaurantes, boates, casas noturnas, entre outros, começaram a investir em produtos e serviços destinados às necessidades dos casais de lésbicas e gays e também do contingente de solteiros dessas pessoas, focados no grande poder de consumo desse público ávido por entretenimento, lazer e disposto a gastar mais por serviços e equipamentos turísticos de qualidade.

Diante da atual conjuntura de conquistas envolvendo o direito ao casamento civil, planos de saúde conjuntos, herança, adoção e previdência, a situação de lésbicas e gays no Brasil é bem melhor do que há sete anos. A diversidade hoje conseguiu maior respeito e aceitação social. Embora seja inevitável o convívio com a homofobia/lesbofobia/transfobia, hoje já existem leis que inibem essa prática.

Os ataques físicos contra homossexuais e os crimes de intolerância são punidos 
devidamente. As mídias têm colaborado para a visibilidade da causa LGBT, em geral, de forma afirmativa. As conquistas do movimento homossexual pelos direitos iguais têm encorajado pessoas públicas e famosas a se assumirem, fortalecendo, assim, a luta e o respeito pela causa. De acordo com essas considerações, refletimos ser de grande importância a implementação de políticas públicas voltadas para o atendimento das pessoas homossexuais.

\section{Referências}

BALDI, Fernanda. Casamento e conjugalidade: núcleo de atendimento social sistêmico. Disponível em:<http://nassistemico.blogspot.com.br/2011/08/casamento-e-conjugalidade.html. Acesso em: 16 out. 2013.

DIAS, Maria Berenice Dias. Legislação brasileira e homofobia. In: VENTURI, Gustavo; BOKANY, Vilma (Org.). Diversidade sexual e homofobia no Brasil. São Paulo: Instituto Rosa Luxemburg, 2011. p. 163-174.

LOREA, Roberto Arriada. Acesso ao casamento no Brasil: um questão de cidadania sexual. Revista Estudos Feministas, Florianópolis, v.14, n. 2, p. 488-496, maio/ago. 2006.

MEDEIROS, Camila Pinheiro. Uma família de mulheres: ensaio etnográfico sobre homoparentalidade na periferia de São Paulo. Revista Estudos Feministas, Florianópolis, v.14, n. 2, p. 535-537, maio/ago. 2006.

MELLO, Luiz. Familismo (anti) homossexual e regulação da cidadania no Brasil. Revista Estudos Feministas, Florianópolis, v.14, n. 2, p. 497-508, maio/ago. 2006.

MESQUITA, Margarida. Parentalidade: contributo para uma definição do conceito. Plataforma Barômetro Social. Disponível em: $<$ http://barometro.com.pt/archives/889>. Acesso em: 17 out. 2013.

MOTT, Luiz. Homo-afetividade e direitos humanos. Revista Estudos Feministas, Florianópolis, v.14, n. 2, p. 509-521, maio/ago. 2006.

PELÚCIO, Larissa. Três casamentos e algumas reflexões: notas sobre conjugalidade envolvendo travestis que se prostituem. Revista Estudos Feministas, Florianópolis, v.14, n. 2, p. 522-534, maio/ago. 2006.

UZIEL, Anna Paula; MELLO, Luiz; GROSSI, Miriam. Conjugalidades e parentalidades de gays, lésbicas e transgêneros no Brasil. Revista Estudos Feministas, Florianópolis, v.14, n. 2, p. 481-487, maio/ago. 2006. 